\title{
39. DATA REPORT: RESULTS OF GEOCHEMICAL WELL LOGGING IN THE IZU-BONIN FOREARC BASIN, SITES 782 AND 786, LEG $125^{1}$
}

\author{
Elizabeth Lewis Pratson, ${ }^{2}$ Mike Hobart, ${ }^{2}$ and Cristina Broglia ${ }^{2}$
}

\begin{abstract}
Geochemical well logs were obtained both in sediments and in basalts at Sites 782 and 786 during Leg 125. Corrections have been applied to these logs to account for variations in hole size, interference of drilling fluids, and drill-pipe effects. Calcium carbonate and oxide weight percentages have been calculated from the processed logs and have been compared to the available core measurements. The log-derived carbonate curve is compared to shipboard $\mathrm{CaCO}_{3}$ measurements in Hole 782B and in the upper portion of Hole $786 \mathrm{~B}$, and the two show reasonable agreement. Instrumental neutron activation analysis measurements have been compared to the natural gamma-ray measurements in Hole 786B; poor agreement exists between the log and core data for Th and $\mathrm{U}$, most likely due to the very low concentration of these two elements. The numerous X-ray fluorescence measurements, performed for the basement section of Hole 786B, show excellent agreement with the logs, with the exception of $\mathrm{MgO}$ in the $\mathrm{Mg}$-rich basalt units.
\end{abstract}

\section{INTRODUCTION}

Ocean Drilling Program (ODP) Leg 125 took place in the Mariana and Izu-Bonin forearcs, located in the western Pacific Ocean. The main objective of Leg 125 was to answer questions regarding the magmatic, tectonic, and sedimentary evolution of forearc terrains. Previous wells have been drilled in the Mariana forearc (Deep Sea Drilling Project Leg 60, Sites 458 and 459); Leg 125, however, was the first to obtain geochemical logs in a forearc terrain. Geochemical logs provide continuous measurements of the major elements in the formation, a capacity which is invaluable in this area, as core recovery has been low. This study will discuss the geochemical logging results from Sites 782 and 786, located in the Izu-Bonin forearc basin. Objectives of these particular two sites were (1) to determine the stratigraphy of the forearc sediments for implications concerning volcanic and tectonic history and (2) to understand the nature of the igneous basement that forms the forearc.

Nine sites were drilled during Leg 125 , but, because of unstable hole conditions (Sites 778, 779, 783, and 785), cable head problems (Site 780), bit failure (Site 784), and a shallow hole (Site 781), only two were logged. A full suite of processed geochemical logs from Sites 782 and 786 are presented in this paper. This report will (1) discuss the hole conditions and logging operations at each site, (2) outline the basic principles of the geochemical tools, (3) explain the data processing techniques, and (4) present the final oxide measurements calculated from the logs and compare them to available core measurements.

\section{DATA ACQUISITION}

\section{Site 782}

Despite the heavy seas encountered during the drilling of Hole $782 \mathrm{~A}$, excellent core recovery was achieved to a depth of $399.5 \mathrm{mbsf}$, where ash layers were encountered and recovery decreased significantly. At $470 \mathrm{mbsf}$ andesites were encountered and the drilling rate was greatly reduced. The drill pipe stuck during hole penetration and had to be severed with explosives. The hole was abandoned, and a second hole, Hole 782B, was washed to basement and then drilled in an attempt to reach the basement objectives. In anticipation of hole

\footnotetext{
'Fryer, P., Pearce, J. A., Stokking, L. B., et al., 1992. Proc. ODP, Sci. Results, 125 College Station, TX (Ocean Drilling Program).

${ }^{2}$ Lamont-Doherty Geological Observatory of Columbia University, Palisades, NY 10964, U.S.A.
}

problems, 10 barrels of high viscosity mud were pumped into the hole following each pipe connection (approximately every $9.5 \mathrm{mbsf}$ ). Increases in pump pressure and torque while cutting the first core lead to the decision to stop coring. The hole was washed to 459.3 mbsf. A final 9.6-m core was retrieved, which brought the total depth to 468 mbsf.

In preparation for logging, the hole was filled with potassium chloride mud and the bottom-hole assembly (BHA) was raised to 71 mbsf. Two logging runs were completed successfully: the first carried a seismic stratigraphic string consisting of phasor induction, lithodensity, sonic, and natural gamma-ray tools and was logged open hole from 453 to 105 mbsf; the second carried the geochemical string, which includes gamma-ray spectrometry, aluminum clay, and natural gamma-ray tools, and was logged open hole from 453 to $105 \mathrm{mbsf}$ and through pipe from $105 \mathrm{mbsf}$ to $10 \mathrm{~m}$ above the mudline. Because time was limited and the data were poor, the through-pipe data in Hole 782B have not been processed and are not presented here.

\section{Site 786}

Drilling was abandoned at Site 785 , leaving time to proceed to an alternate site. Site 786 was chosen in hopes of obtaining more basement samples in the Izu-Bonin forearc. Hole 786A was cored to basement (a depth of $166.5 \mathrm{mbsf}$ ) with excellent recovery. Hole 786B was then spudded and washed to $162.6 \mathrm{mbsf}$, where coring began. Difficult drilling conditions were anticipated; 10 barrels of high-viscosity mud were added at every third pipe connection (almost every $28 \mathrm{~m}$ ). While cutting the first few cores, the pipe became stuck in the hole. Hole problems were then decreased by adding the 10 barrels of mud at each connection. To allow enough time for logging, drilling stopped at a final depth of $828.6 \mathrm{mbsf}$.

During the wiper trip made in preparation for logging, a hole constriction was indicated between 776.6 to $806.6 \mathrm{mbsf}$. The hole was reamed out and then was injected with potassium chloride mud. The first logging string, the seismic stratigraphic combination, hit a bridge at $420 \mathrm{mbsf}$ and could not be deployed further. Logs were recorded open hole from 462 to $108 \mathrm{mbsf}$. The second tool string, composed of the lithodensity, neutron, and natural gamma-ray tools, also hit a bridge at $376.1 \mathrm{mbsf}$ and so was logged open hole from this depth to 110 mbsf.

After the second logging run, the Schlumberger equipment was removed, and bridges were cleared by rotating the drill pipe. The BHA was kept at $437.6 \mathrm{mbsf}$ so that the lower section of the hole could be logged. The seismic stratigraphic string was run again open hole from 
810 to 453.2 mbsf. Finally, the geochemical logging string was run open hole from $810 \mathrm{mbsf}$ to $461.3 \mathrm{mbsf}$ and through pipe from 461.3 mbsf to the mud line.

Electrical and acoustical logs do not work through pipe, as electrical currents and sound waves do not propagate through steel. Neutrons and gamma rays, however, can pass and be detected through pipe; thus, geochemical and radioactive logs can still be recorded. The signal detected from the formation when run through pipe is greatly attenuated, which results in a decreased signal-to-noise ratio. The through-pipe sections of logs from Hole 786B were processed and will be presented; however, the data was not as high quality as that of the lower, open-hole sections.

\section{GEOCHEMICAL TOOL STRING}

The geochemical logging tool string (GLT) consists of four separate logging tools: the natural gamma-ray tool (NGT), the compensated neutron tool (CNT), the aluminum activation clay tool, (AACT), and the gamma-ray spectrometry tool (GST; Fig. 1) (GLT, NGT, CNT, AACT, and GST are trademarks of Schlumberger). The NGT is located at the top of the tool string, so that it can measure the naturally occurring radionuclides $\mathrm{Th}, \mathrm{U}$, and $\mathrm{K}$ before the formation is irradiated by the nuclear sources mounted on following tools. The compensated neutron tool, located below the natural gamma-ray tool, carries a low-energy neutron source $\left(\mathrm{Cf}^{252}\right)$ to activate the aluminum atoms in the formation. The aluminum activation clay tool, a modified NGT, follows the $\mathrm{Cf}^{252}$ source and measures the activated gamma rays in the formation. By combining this measurement with the previous NGT measurement, the background radiation is subtracted out and a reading of formation $\mathrm{Al}$ is obtained (Scott and Smith, 1973). The gamma-ray spectrometry tool, located at the bottom of the string, carries both a pulsed-neutron generator to bombard the borehole and the formation and a NaI scintillation counter to measure the spectrum of gamma rays generated by neutron capture reactions. Because each of the elements in the formation is characterized by a unique spectral signature, it is possible to derive the contribution (or yield) of the major elements silicon $(\mathrm{Si})$, iron $(\mathrm{Fe})$, calcium $(\mathrm{Ca})$, titanium $(\mathrm{Ti})$, sulfur $(\mathrm{S})$, gadolinium $(\mathrm{Gd})$, and potassium $(\mathrm{K})$ to the measured spectrum and, in turn, to estimate their abundances in the formation. The GST also measures hydrogen $(\mathrm{H})$ and chlorine $(\mathrm{Cl})$ in the borehole and formation; however, these elements are not used when determining rock geochemistry.

The only major rock-forming elements not measured by the geochemical tool string are magnesium $(\mathrm{Mg})$ and sodium $(\mathrm{Na})$; the neutron-capture cross sections of these elements are too small to be detected by the GST. One can roughly estimate their abundances by using the photoelectric factor (PEF), measured by the lithodensity tool. The measured PEF is compared to a calculated PEF, derived by summing the PEF values expected from all the other measured elements. The difference between the measured and calculated PEF is attributed to any element left over in the formation, mainly $\mathrm{Mg}$ and $\mathrm{Na}$. This calculation was performed at Holes 782B and 786B and yielded zero $\mathrm{Mg}$ throughout Hole 786B, except for a few erratic spikes. Recovered core samples indicated that this was not correct; therefore, $\mathrm{Mg}$ was calculated based on an assumed constant relationship between $\mathrm{MgO}, \mathrm{FeO}^{*}$ (sum of $\mathrm{FeO}$ and $\mathrm{Fe}_{2} \mathrm{O}_{3}$ ), and $\mathrm{SiO}_{2}$ :

$$
\left.\mathrm{FeO}^{*}+\mathrm{MgO}=577.5 \times 10^{(-.0365} \mathrm{SiO}_{2}\right) .
$$

A similar Mg equation is routinely used by Schlumberger when logging in carbonate sequences typically encountered in oil field wells. Their equation assumes a dolomite mineralogy and a constant relationship between $\mathrm{CaCO}_{3}$ (calcite) and $\mathrm{CaMg}\left(\mathrm{CO}_{3}\right)_{2}$ (dolomite). Because a dolomite assumption would be unreasonable in igneous rocks or in igneous-derived lithologies, the program was altered to include a relationship for igneous lithologies between $\mathrm{SiO}_{2}, \mathrm{FeO}^{*}$, and $\mathrm{MgO}$. One mineral type cannot be assumed for a general igneous rock environment; therefore, total oxide values for igneous rocks of all types of igneous and metamorphic rocks were included (granites, tonalites, syentites, monzonites, diorites, andesites, gabbros, and dunites). Our igneous $\mathrm{Mg}$ equation was obtained by looking at the relationship between $\mathrm{FeO}^{*}, \mathrm{SiO}_{2}$, and $\mathrm{MgO}$ in these average igneous rocks (Nockolds, 1954). The $\mathrm{MgO}$ relationship between $\mathrm{FeO}^{*}$ and $\mathrm{SiO}_{2}$ has been successfully used to calculate $\mathrm{MgO}$ in other igneous lithologies (e.g., at Cajon Pass, drilled along the San Andreas fault in California [Anderson et al., 1988], at the Palisades sill located along the Hudson River in New York, and at ODP Hole 504B [Anderson et al., 1990]).

\section{DATA REDUCTION}

The well-logging data from the Schlumberger tools are transmitted digitally up a wireline and then are recorded and processed aboard the JOIDES Resolution in the Schlumberger Cyber Service Unit (CSU). Results from the CSU are made available as "field logs" for initial interpretation at sea. Subsequent reprocessing is necessary to correct the data for the effects of logging conditions, fluids added to the well, logging speed, and drill pipe. Processing of the spectrometry data is required to transform the relative elemental yields into oxide weight fractions.

A set of revised log interpretation programs written by Schlumberger is used to process the data. The processing steps are summarized below:

\section{Reconstruction of Relative Elemental Yields from Recorded Spectral Data}

The first step compares the measured spectra from the geochemical spectrometry tool with a series of standard spectra to determine the relative contribution (or yield) of each element using a leastsquares method. Whereas six elemental standards ( $\mathrm{Si}, \mathrm{Fe}, \mathrm{Ca}, \mathrm{S}, \mathrm{Cl}$, and $\mathrm{H}$ ) are used to produce the yields at sea, three additional standards ( Ti, Gd, K) are used in shore-based processing. Although these additional elements often occur in low concentrations in the formation, their large neutron-capture cross sections enable them to occupy a large portion of the measured spectra. The capture cross section of $\mathrm{Gd}$, for instance, is 49,000 barns; that of $\mathrm{Si}$ is only 0.16 barns (Hertzog et al., 1987). Gd, therefore, although occurring in small abundances in the formation, is included in the calculation for a best-fit of the measured with the standard spectra.

This best-fit analysis was performed at Hole $782 \mathrm{~B}$, where $\mathrm{Si}, \mathrm{Ca}$, $\mathrm{Fe}, \mathrm{S}, \mathrm{K}, \mathrm{Ti}, \mathrm{Gd}, \mathrm{H}$, and $\mathrm{Cl}$ were given as final yields. The spectral analysis in Hole 786B was not redone on shore, since, after logging Hole 786B, the original field data for the main pass of geochemical logs was recorded to disk file instead of to tape and was overwritten during the next leg. The Schlumberger engineer wrote an edited tape with selected curves (but not with the spectral data from the geochemical tool). The tape contained shipboard-computed yields and data from a short repeat section at the bottom of the hole (814.5-788 mbsf) which did have the spectrum. Results of the landprocessed yields in this short repeat section looked comparable to the shipboard-computed yields, and therefore the field-computed yields were used to determine oxides in this well. A 10-point smoothing filter was applied to all yields in both holes to reduce the amplitude of noise in the data. The iron yield in Hole 786B was corrected for effects caused by the iron in the drill pipe and in the BHA by applying an appropriate offset for each pipe thickness.

\section{Depth-Shifting}

The second step is to depth-shift the logging runs to a chosen reference run. A total gamma-ray curve (run on each tool string) was chosen as a reference curve, selected on the basis of cable tension (the logging run with the least amount of cable sticking) and cable speed (faster speeds are less affected by tool sticking). The logs were 


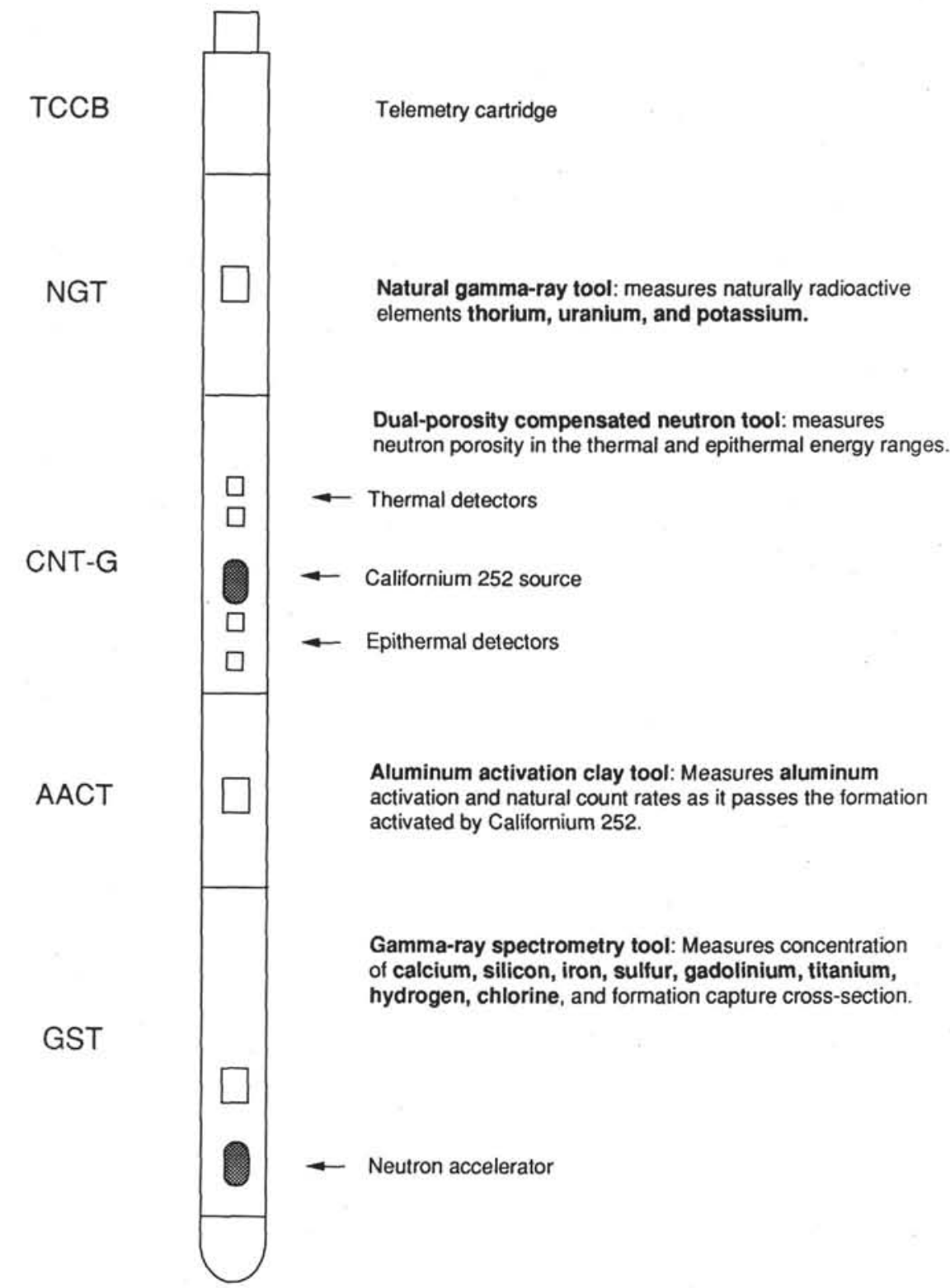

Figure 1. Schematic drawing of the geochemical logging string used by ODP. Note that a boron sleeve was not present on the geochemical tool on Leg 125; however, the tool has since been modified for ODP to include this boron sleeve to mask out iron readings from the tool.

depth-referenced to the geochemical tool string at Hole 782B and to a spliced gamma-ray curve from the first and third logging runs (seismic stratigraphic and geochemical, respectively) at Hole 786B.

\section{Calculation of Total Radioactivity and Th, $U$, and $K$ Concentration}

The third routine calculates the total natural gamma-ray radiation in the formation and the concentrations of Th, $\mathrm{U}$, and $\mathrm{K}$, by using the counts in five spectral windows from the natural gamma-ray tool (Lock and Hoyer, 1971). This process is similar to what is done at sea except that corrections for changes in hole size are made during shorebased processing of these curves. A Kalman filter (Ruckebusch, 1983) is used to correct for statistical errors in the logs, which often create erroneous negative readings and anti-correlations (especially between $\mathrm{Th}$ and $\mathrm{U}$ ). At each depth calculations and corrections were also performed for $\mathrm{K}$ contained in the mud. This $\mathrm{K}$ correction is particular- ly useful for ODP since $\mathrm{KCl}$ is routinely added to the hole; however, as a result of dilution, it is difficult to know exactly how much $\mathrm{K}$ is actually in the borehole. The outputs of this program are $\mathrm{K}$ (wet $\mathrm{wt} \%), \mathrm{U}(\mathrm{ppm})$, and Th (ppm), along with a total gamma-ray curve and a computed gamma-ray curve $(\mathrm{Th}+\mathrm{K})$.

\section{Calculation of Al Concentration}

The fourth routine calculates an aluminum curve using four energy windows from the AACT while simultaneously correcting for the borehole fluid neutron-capture cross section, the formation neutroncapture cross section, the formation slowing-down length, and the borehole size. Porosity and density logs are needed in this routine to convert the wet weight percentage of $\mathrm{K}$ and $\mathrm{Al}$ curves to dry weight percentage. In Holes $782 \mathrm{~B}$ and $786 \mathrm{~B}$ the density logging curves were in close agreement with the core measurements, while the porosity 
curves from both the sonic and neutron tools deviated quite a bit from the core measurements. Therefore, a porosity curve was calculated from the density curve in each hole.

A correction was also made for $\mathrm{Si}$ interference with $\mathrm{Al}$. Si can become activated by the $\mathrm{Cf}^{252}$ source, causing a reaction that produces the aluminum isotope, $\mathrm{Al}^{28}$ (Hertzog et al., 1987). The program uses the Si yield from the gamma-ray spectrometry tool to determine the background correction for $\mathrm{Si}$. The program outputs dry weight percentages of $\mathrm{Al}$ and $\mathrm{K}$, which are used to calculate and normalize the remaining elements.

\section{Normalization of Al and $K$ with Elemental Yields to Calculate the Elemental Weight Fractions}

The next routine takes the dry weight percentages of $\mathrm{Al}$ and $\mathrm{K}$ and normalizes them with the reconstructed yields to obtain dry weight percentages of the elements, using the following relationship:

$$
W t_{i}=F Y_{i} / S_{i}
$$

where $W t_{i}=$ absolute elemental concentration, $F=$ normalization factor, $Y_{i}=$ relative elemental yield, and $S_{i}=$ spectral sensitivity factor. The normalization factor, $F$, is a calibration factor determined at each depth to account for the presence of $\mathrm{C}$ and $\mathrm{O}$ associated with each element. Because the sum of oxides in a rock is $100 \%, F$ is given by

$$
F\left[\sum X_{i}\left(Y_{i} / S_{i}\right)\right]+X_{K} W t_{K}+X_{A l} W t_{A l}=100
$$

where $X_{i}=$ dry wt $\%$ of oxide or carbonate divided by dry wt $\%$ of element $i, Y_{j}=$ fraction of spectra attributed to element $i, X_{K}=$ dry $\mathrm{wt} \%$ of oxide of element $\mathrm{K}$ divided by dry wt $\%$ of $\mathrm{K}, W t_{K}=$ dry $\mathrm{wt} \%$ $\mathrm{K}, X_{A l}=$ dry $w t \%$ of oxide of element Al divided by dry wt $\%$ of $\mathrm{Al}$, and $W t_{A l}=$ dry wt $\% \mathrm{Al}$. The sensitivity factor, $S_{i}$, is a tool constant, measured in the laboratory, that depends on the capture cross section of each element measured by the geochemical tool (Hertzog et al., 1987). In the carbonate/oxide calculation in Holes $782 \mathrm{~B}$ and 786B we alternatively used $\mathrm{CaO}$ or $\mathrm{CaCO}_{3}$ based on the dominance of carbonate- or $\mathrm{CaO}$-bearing minerals described in the core. $\mathrm{A}$ factor for $\mathrm{CaCO}_{3}$ (2.497) is used in the upper sedimentary section of each hole (Unit I, 0-409.2 mbsf in Hole 782B, and Unit I and II, 0-103.25 mbsf in Hole 786B). The oxide factor for $\mathrm{CaO}$ (1.399) is used in the volcanic breccia and basement sections of each hole.

In this routine, a $\mathrm{Mg}$ curve can be calculated either by using a PEF from the lithodensity tool (as was done in Hole 782B) or by using an assumed constant ratio in igneous rocks of $\mathrm{Si}$ to $\mathrm{Mg}+\mathrm{Fe}$ (equation 1). This ratio was used in the basement section of Hole 786B because the PEF calculation of $\mathrm{Mg}$ incorrectly resulted in a zero-value curve with a few erratic spikes.

\section{Calculation of Oxide Percentages}

The sixth and last routine simply multiplies the percentage of each element by its associated oxide/carbonate factor (Table 1), using the same factor assumed in normalization (step 5).

\section{RESULTS}

\section{Site 782}

The processed natural gamma-ray curves from Hole $782 \mathrm{~B}$ are shown in Figure 2. The natural gamma-ray tool was run on each of the two tool strings and each pass has been reprocessed. The logs presented in Figure 2 have been spliced to maximize the best data. The interval from 0 to 105 mbsf comes from the geochemical run, which has not been corrected for pipe; the interval from 105 to 453 mbsf is from the seismic stratigraphic run that was recorded open hole.
Table 1. Oxide/carbonate factors used to normalize elements to $100 \%$ and to convert elements to oxides/carbonates.

\begin{tabular}{lcc}
\hline Element & Oxide/carbonate & Conversion factor \\
\hline $\mathrm{Si}$ & $\mathrm{SiO}_{2}$ & 2.139 \\
$\mathrm{Ca}$ & $\mathrm{CaO}$ & 1.399 \\
& $\mathrm{CaCO}_{3}$ & 2.497 \\
$\mathrm{Fe}$ & $\mathrm{FeO}^{*}$ (total iron) & 1.358 \\
$\mathrm{~K}$ & $\mathrm{~K}_{2} \mathrm{O}$ & 1.205 \\
$\mathrm{Ti}$ & $\mathrm{TiO}_{2}$ & 1.668 \\
$\mathrm{Al}$ & $\mathrm{Al}_{2} \mathrm{O}_{3}$ & 1.899 \\
$\mathrm{Mg}$ & $\mathrm{MgO}$ & 1.658 \\
\hline
\end{tabular}

The calculations of Th, U, and $\mathrm{K}$ are greatly improved over the shipboard results: in fact, the uranium value, negative in the field logs (Fryer, Pearce, Stokking, et al., 1990), is now positive with improved calibration.

Figure 3 displays the oxide and $\mathrm{CaCO}_{3}$ weight fractions estimated from the logs at Hole 782B compared with core measurements, and one can see good agreement between the two.

\section{Site 786}

The processed natural gamma-ray logs from Hole 786B are displayed in Figure 4. These data come from the open-hole passes of the seismic stratigraphic run (0-462 mbsf) and the geochemical tool string in the lower portion of the hole (462-810 mbsf). The logs are compared to the core measurements taken by instrumental neutron activation analysis (INAA) (Fryer, Pearce, Stokking, et al., 1990). Th and $U$ values in the logs are much lower than those in the core measurements, possibly because of the very low radioactive content of the formation. On the other hand, logged potassium value shows excellent agreement with core data.

The oxide weight fractions for Hole 786B are shown in Figure 5. While sediment lithologic Units I and II are not discriminated by the logs, Unit III (103-125 mbsf) is marked by an increase in $\mathrm{K}_{2} \mathrm{O}$.

$\mathrm{X}$-ray fluorescence (XRF) measurements are displayed with the logs in the basement section of the well (Fryer, Pearce, Stokking, et al., 1990), where they show excellent agreement with core. Only the $\mathrm{MgO} \log$ is noisy and deviates from the core between 511 and 728 mbsf. This is probably because the assumption made for the $\mathrm{MgO}$ calculations is not valid in the "Mg-rich" basal boninite breccias found in this interval.

\section{CONCLUSIONS}

The reprocessing of natural gamma-ray logs improves the measurements calculated in the field. Geochemical logs can be converted to elemental and oxide measurements, which compare well with core data. When core data are missing, the reprocessed logs are an invaluable data set from which to interpret the lithology.

\section{REFERENCES}

Anderson, R. N., and Alt, J. C., Malpas, J., Lovell, M. A., Harvey, P. K., Lewis Pratson, E., 1990. Geochemical well logging in basalts: the Palisades sill and the oceanic crust of 504B. Geophys. Res., 95:9265-9292.

Anderson, R. N, Dove, R. E., Broglia, C., Silver, L., James, E., Chappel, B., 1988. Elemental and mineralogical analyses from geochemical logs from Cajon Pass scientific drill hole, and their preliminary comparison with core analyses. Geophys. Res. Lett., 15:969-972.

Fryer, P., Pearce, J. A., Stokking, L. B., et al., 1990. Proc, ODP, Init. Repts., 125: College Station, TX (Ocean Drilling Program). 

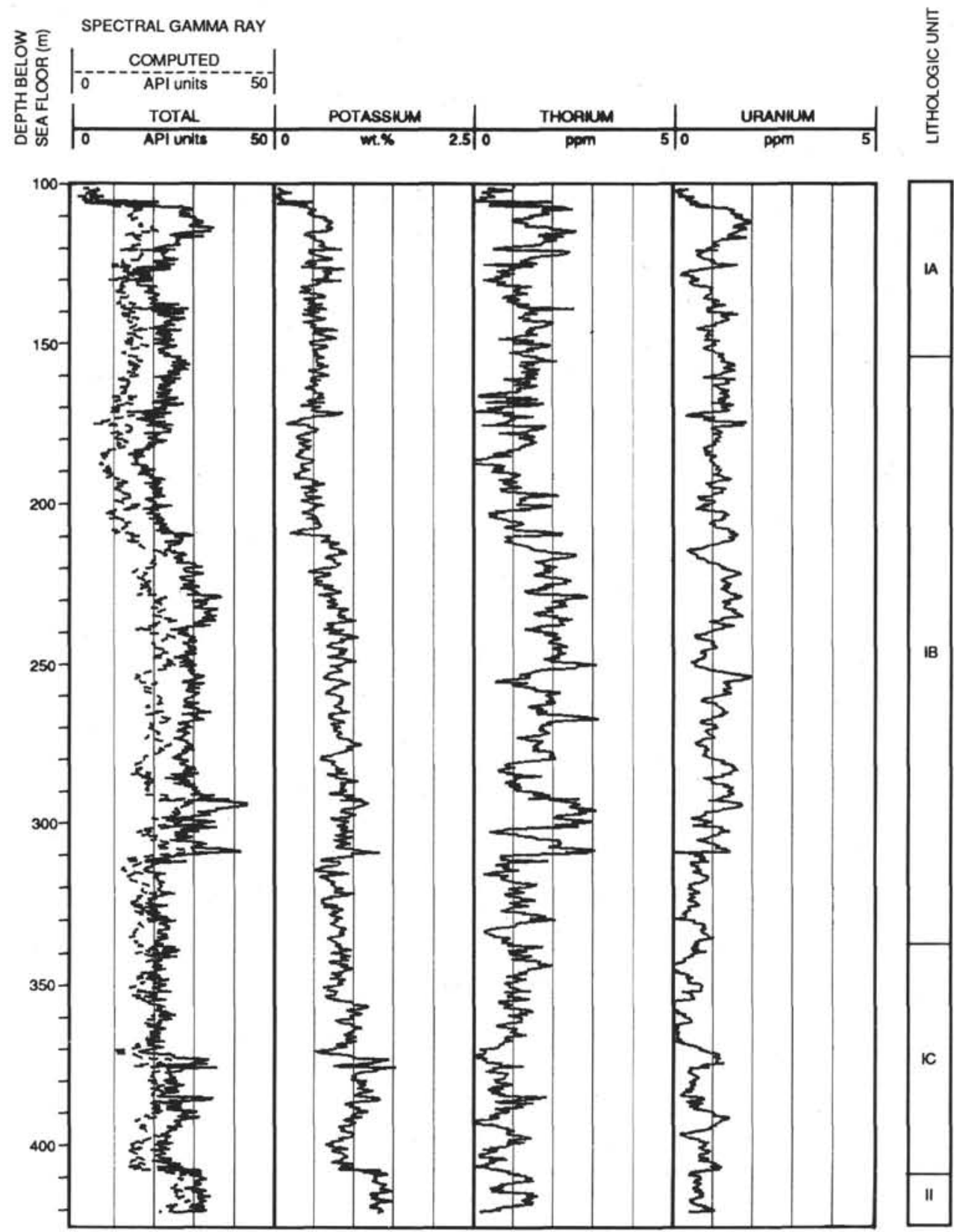

Figure 2. Processed natural gamma-ray data from Hole 782B. Lithology is described as Subunit IA = nannofossil marl, Subunit IB = vitric nannofossil marl, Subunit IC = nannofossil and vitric nannofossil chalk, and Unit II = andesites. 
Hertzog, R., Colson, L., Seeman, B., O’Brien, M., Scott, H., McKeon, D., Wraight, P., Grau, J., Schweitzer, J., and Herron, M., 1987. Geochemical Logging With Spectrometry Tools. Soc. Pet. Eng. Pap., 16792.

Lock, G. A., and Hoyer, W. A., 1971. Natural gamma-ray spectral logging. Log Analyst, 12:3-9.

Nockolds, S. R., 1954. Average chemical composition of some igneous rocks. Geol. Soc. Am. Bull., 65:1007-1032.

Ruckebusch, G., 1983. A Kalman filtering approach to natural gamma-ray spectroscopy in well logging. IEEE Trans., AC-28:372-380.
Scott, H. D., and Smith, M. P., 1973. The aluminum activation log. Log Analyst, $14: 3-12$.

Date of initial receipt: 1 October 1990

Date of acceptance: 18 March 1991

Ms 125B-179 
고을

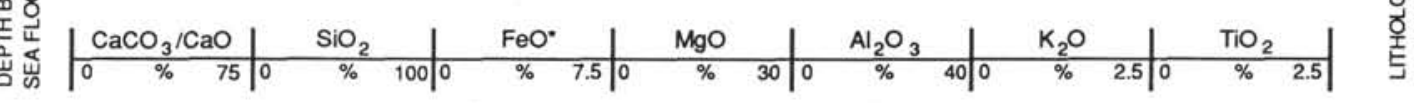

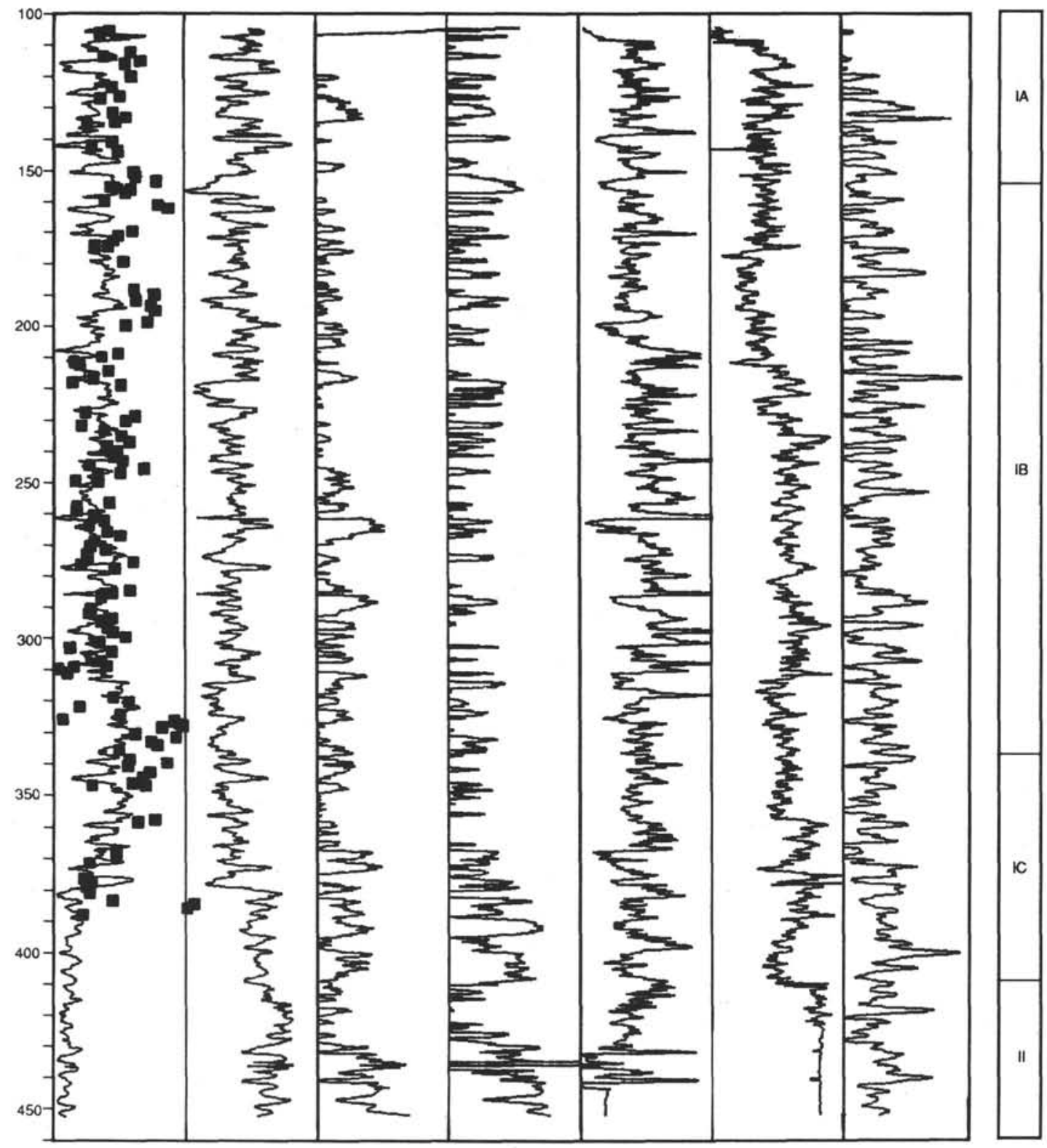

Figure 3. Estimates of the major oxide and calcium carbonate weight fractions from geochemical logs in Hole 782B. Squares represent $\mathrm{CaCO}_{3}$ values from core (Fryer, Pearce, Stokking, et al., 1990). 

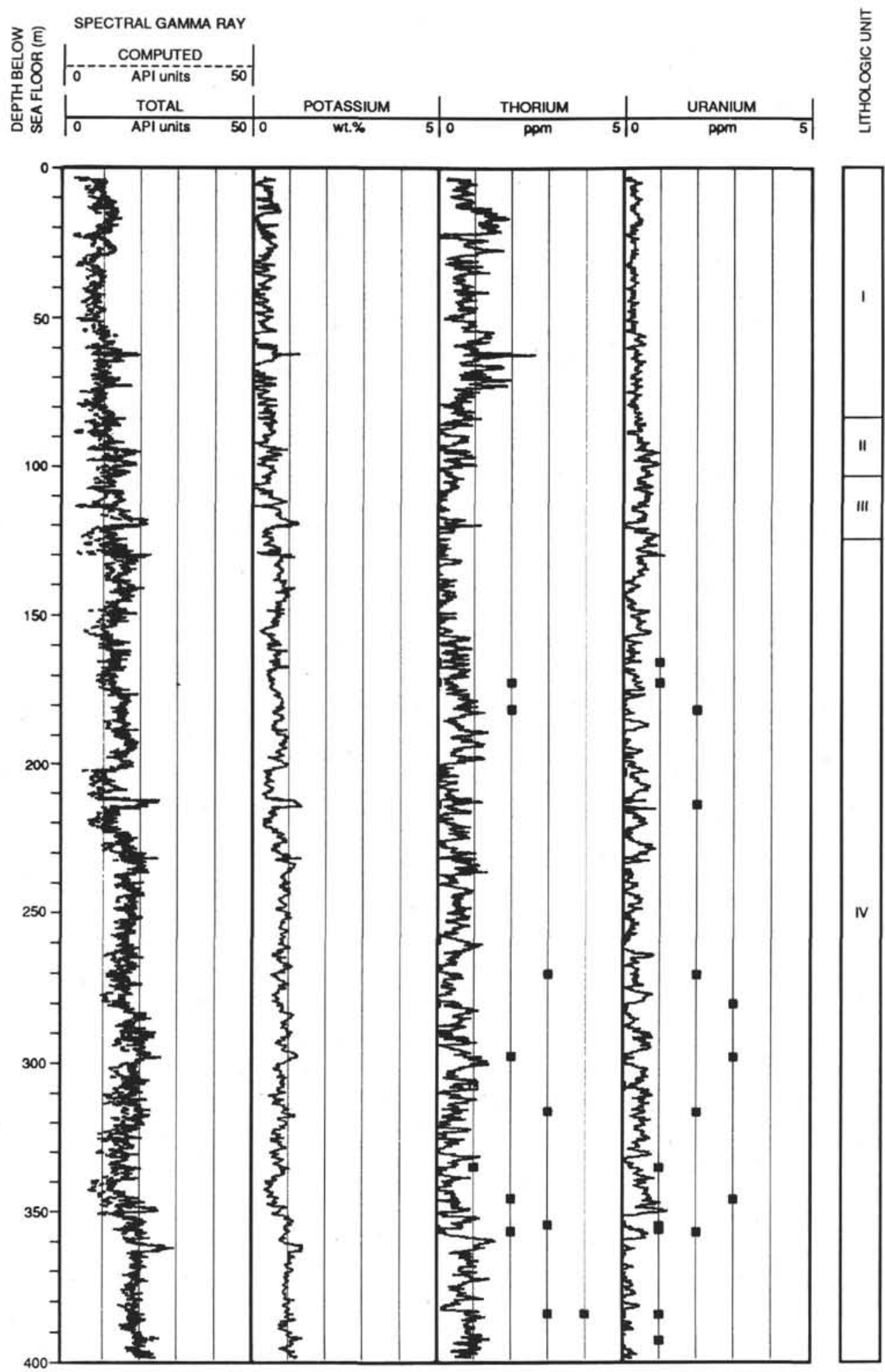

Figure 4. Processed natural gamma-ray data from Hole 786B, compared to INAA measurements from core (Fryer, Pearce, Stokking, et al., 1990). Lithology is described as Unit I = nannofossil marl and nannofossil/glass-rich clay, Unit II = nannofossil marl and glass-rich clay, Unit III = volcanic breccia, and Unit IV = igneous rocks . 

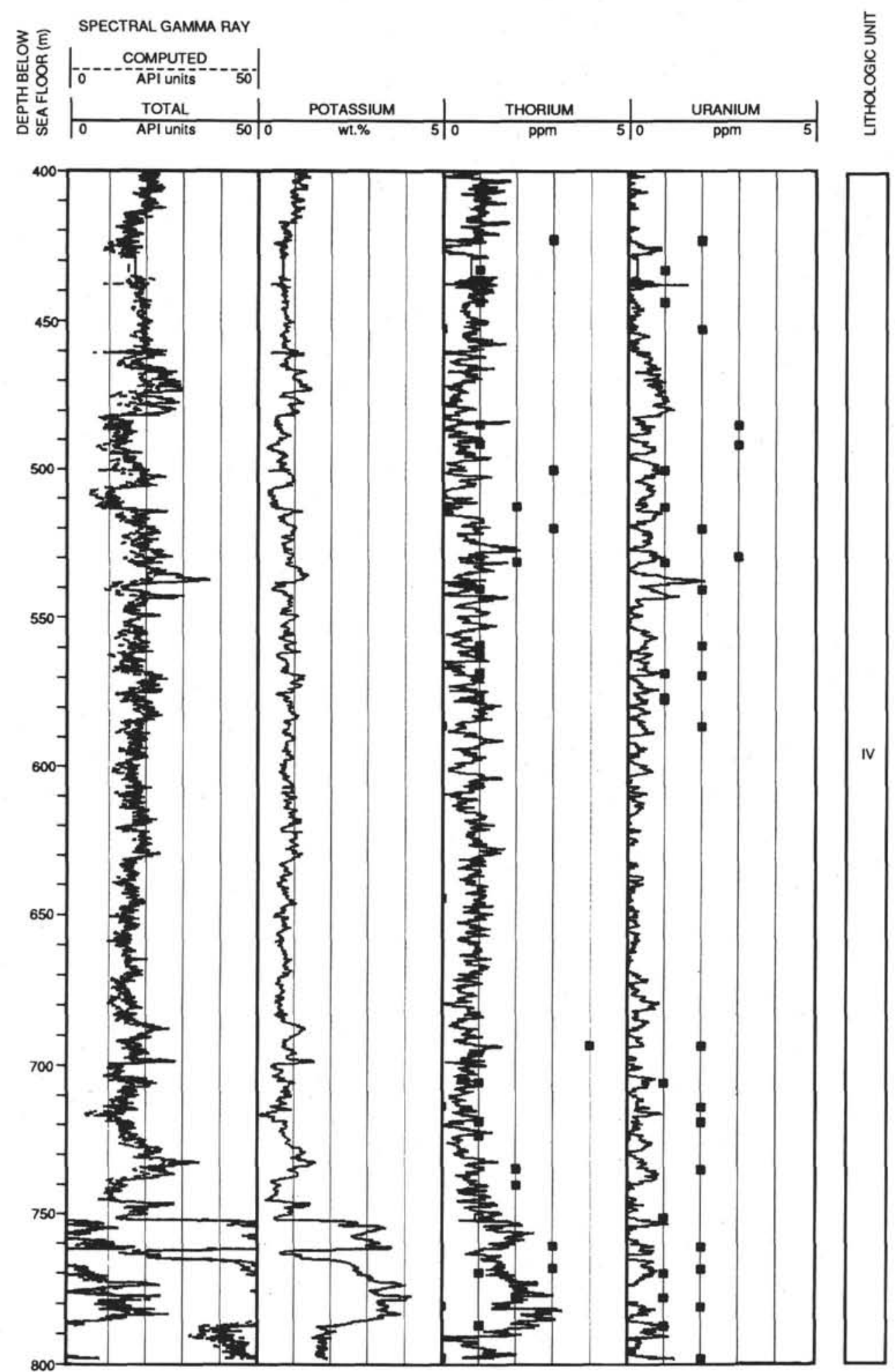

Figure 4 (continued). 


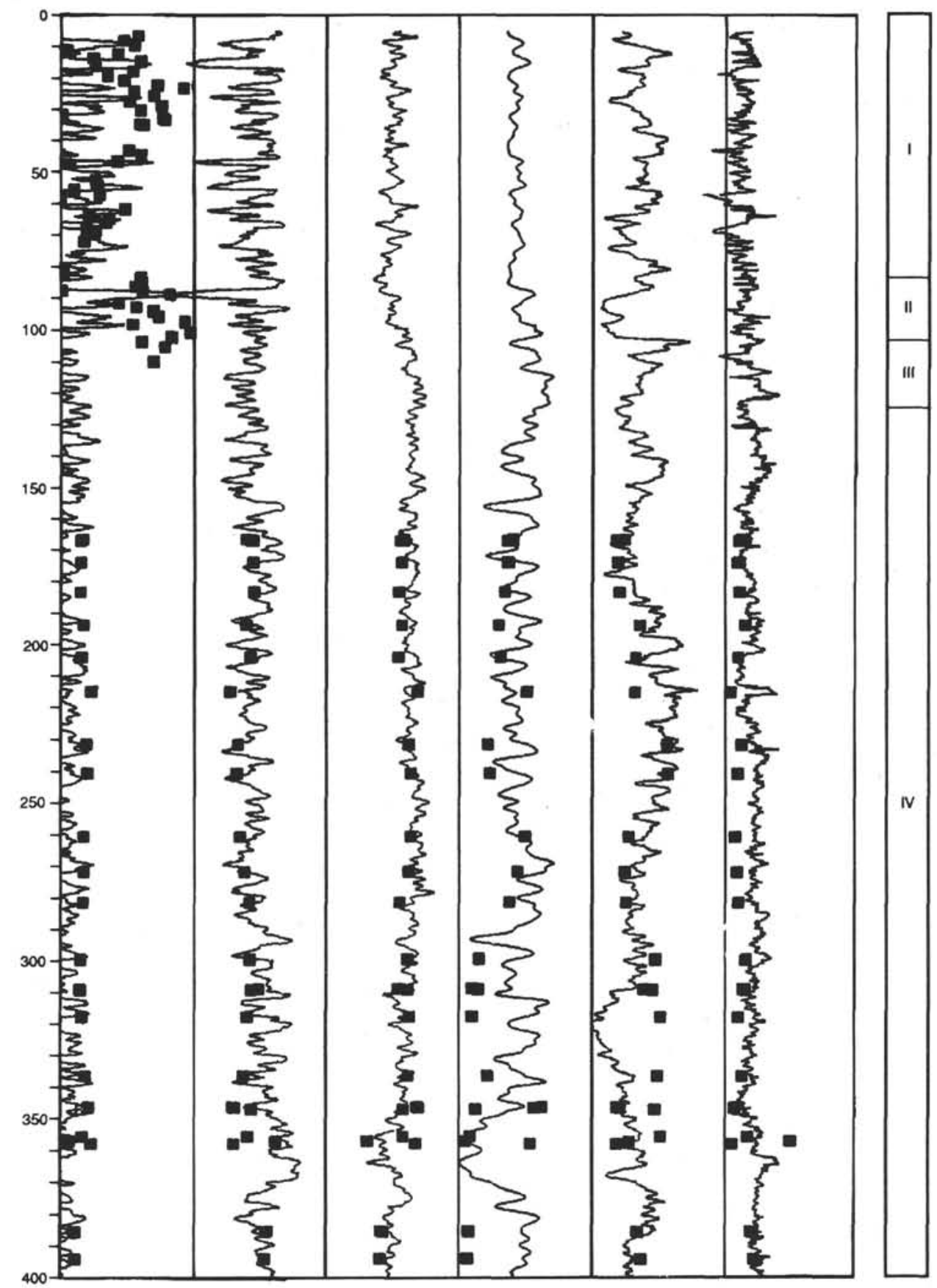

Figure 5. Estimates of the major oxide weight fractions from geochemical logs in Hole 786B compared to XRF analysis (Fryer, Pearce, Stokking, et al., 1990). The logs and core show excellent agreement, except for MgO in the Mg-rich boninite breccias. 


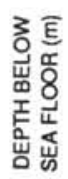
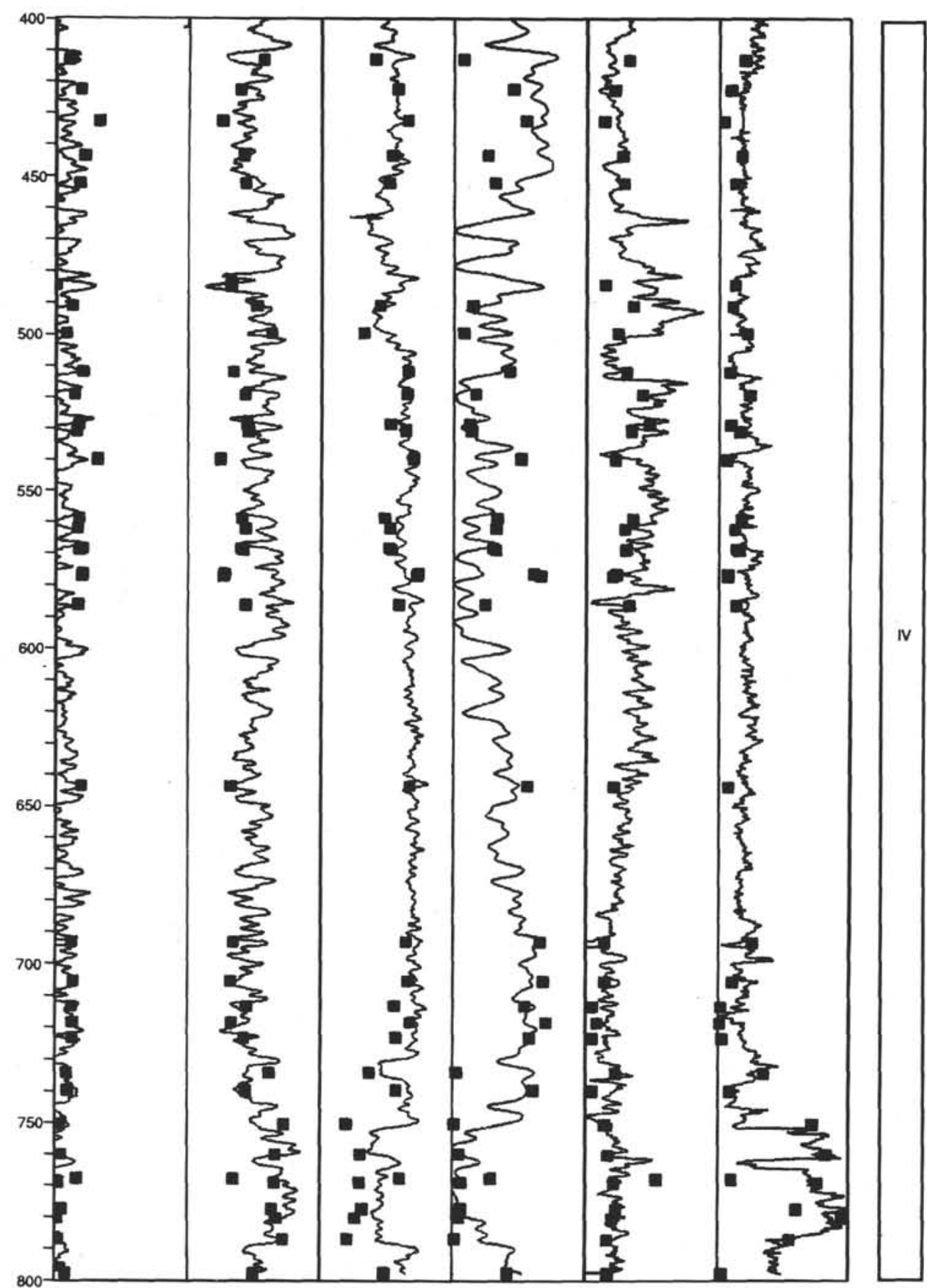

Figure 5 (continued). 